\title{
Egg-White Mediated Sol-Gel Synthesis of Cobalt Ferrites and Their Electrocatalytic Activity Towards Alkaline Water Electrolysis
}

\author{
Narendra Kumar Singh*, Manish Kumar Yadav, Reena Parihar and Chinky Gangwar \\ Department of Chemistry, Faculty of Science, University of Lucknow, Lucknow-226007 (INDIA)
}

Corresponding Author Email: *nksbhu@yahoo.com; singh_narendra@lkouniv.ac.in

\begin{abstract}
This research manuscript deals the electrocatalytic properties of spinel-type oxides of Co and $\mathrm{Fe}$ having composition $\mathrm{Co}_{\mathrm{x}} \mathrm{Fe}_{3-\mathrm{x}} \mathrm{O}_{4}(0 \leq \mathrm{x} \leq 1.5)$ which is synthesized by natural egg-white mediated sol-gel route. Physicochemical studies (IR and XRD) indicated the formation of almost pure spinel phase of the oxide. Morphological structure in the form of film on $\mathrm{Ni}$-support was observed to be the same except $\mathrm{CoFe}_{2} \mathrm{O}_{4}, \mathrm{which}$ showed some aggregation on the surface of support. For electrochemical characterizations, the oxide powder was transfered to film electrode on the pre-treated $\mathrm{Ni}$ - support. The cyclic voltammogram $(\mathrm{CV})$ recorded in $1 \mathrm{M} \mathrm{KOH}$ at $25^{\circ} \mathrm{C}$ in the potential region $0.0-0.7 \mathrm{~V}$ showed a pair of redox peaks, one anodic $\left(\mathrm{E}_{\mathrm{Pa}}=512 \pm 12 \mathrm{mV}\right)$ and corresponding cathodic $\left(\mathrm{E}_{\mathrm{Pc}}=359 \pm 10 \mathrm{mV}\right)$, prior to oxygen evolution reaction $(\mathrm{OER})$. The anodic polarization study showed that the substitution of $\mathrm{Co}$ for $\mathrm{Fe}$ in the $\mathrm{Fe}_{3} \mathrm{O}_{4}$ lattice marginally improved the electrocatalytic activity of the materials and it is found to the greatest with $0.5 \mathrm{~mol} \mathrm{Co-substitution.} \mathrm{The} \mathrm{substitution} \mathrm{of} \mathrm{Co} \mathrm{increased} \mathrm{the} \mathrm{Tafel} \mathrm{slope} \mathrm{value,} \mathrm{but} \mathrm{the} \mathrm{order} \mathrm{of}$ reaction was almost unity with each electrocatalyst. The standard electrochemical enthalpy of activation $\left(\Delta \mathrm{H}_{\mathrm{el}}^{\circ \neq}\right)$, standard enthalpy of activation $\left(\Delta \mathrm{H}^{\circ} \neq\right)$ and standard entropy of activation $\left(\Delta \mathrm{S}^{\circ} \neq\right)$ have been determined by recording the anodic polarization at different temperatures. The value of $\Delta \mathrm{H}_{\mathrm{el}}^{\circ \neq}$ was found to be minimum with most active $\mathrm{Co}_{0.5} \mathrm{Fe}_{2.5} \mathrm{O}_{4}$ electrode.
\end{abstract}

Keywords: spinel ferrites, egg white, sol-gel, electrocatalysis, oxygen evolution, thermodynamic parameters Received: February-09-2020, Accepted: April-20-2020, https://doi.org/10.14447/jnmes.v23i2.a05

\section{INTRODUCTION}

The present scenerio of world's energy consumption reveals that the resources of main source of energy like coal, petroleum and natural gases are exhausting rapidly. Also, these fossil fuels are nonrenewable and emitting noxious gases. So, efforts have been continued to develop low-cost, efficient and ecofriendly renewable source of energy to overcome the drawbacks of fossil fuels. Transition metal oxides having spinel structure are known to be comprehensive electrode materials as anode and cathode for $\mathrm{O}_{2}$ evolution, $\mathrm{Cl}_{2}$ evolution, $\mathrm{O}_{2}$ reduction, $\mathrm{H}_{2}$ formation and organic electrosynthesis [1]. Among spinels, $\mathrm{Fe}_{3} \mathrm{O}_{4}$ and its metal substituted products in the form of binary and ternary have extensively been used as catalysts in the several reactions such as oxidation of butene [2], synthesis of ammonia [3], decomposition of $\mathrm{H}_{2} \mathrm{O}_{2}$ [4, 5], production of chlorine and chlorate [6]. The literature shows that the spinel ferrites generally possess lower electrocatalytic activity for oxygen evolution [7] as compared to that of spinel cobaltites [8-17]. However, physicochemical and electrochemical properties of these ferrospinels can be improved by adopting low temperature routes such as sol-gel, co-precipitation, hydrothermal etc and partial substituting suitable metal ions in the spinel ferrite matrix [18-32]. For instance, Singh et al. used low temperature co-precipitation method [4] and synthesized binary [18-20] and ternary [21-25] ferrites and studied their electrocatalytic properties towards oxygen evolution reaction (OER) in alkaline slutions. The results shows that the electrocatalytic activity is strongly affected by the metal ion substitutions and found to be better in the case of Cr-substituted ternary ferrites. They also studied the effect substrate $(\mathrm{Ni}$ or $\mathrm{Pt}$ ) on the electrocatalytic activity of the oxide. Al-Mayouf et al. [26] adopted hydrothermal mtheod to prepare nickel ferrites and studied their oxygen evolution electrocatalytic activity.

Very recently, we have prepared spinel ferrites [27-32] by using different low temperature synthetic routes and studied the effect of preparation methods and metal ion substitution on the electrocatalytic properties. By adopting the Maensiri et al. [33] egg-white sol-gel route, we synthesized $\mathrm{Ni}$ - and $\mathrm{Mn}$ substituted [29, 30] spinel ferrites towards alkaline water electrolysis. The reason for adopting this method is that about 40 types of proteins [34] are present in a chicken's egg-white, which facilitates the solubility in water and has a tendency to associate with metal ions in solution. Also, these proteins have various functional properties such as gelling, foaming, emulsification, heat setting and binding adhesion [34, 35].

In view of the above facts, we plan to produce Cosubstituted ferrites by using the same egg-white sol-gel method and studied their electrocatalytic properties with regards to oxygen evolution in alkaline medium. The findings of results are described in this paper.

\section{EXPERIMENTAL}

A very simple, natural egg-white mediated sol-gel route [33] has been used to obtain the Co-substituted spinel oxides with composition $\mathrm{Co}_{\mathrm{x}} \mathrm{Fe}_{3-\mathrm{x}} \mathrm{O}_{4}(0 \leq \mathrm{x} \leq 1.5)$. In each synthesis, highly purified $\mathrm{Fe}\left(\mathrm{NO}_{3}\right)_{3} .9 \mathrm{H}_{2} \mathrm{O}$ (Merck, 98\%), $\mathrm{Co}\left(\mathrm{NO}_{3}\right)_{2} \cdot 6 \mathrm{H}_{2} \mathrm{O}$ (Merck, 97\%) were weighed in stoichiometric ratio and then added in the homogenous solution of egg-white $(60 \mathrm{ml})$ and double distilled water (40 $\mathrm{ml})$. The mixed solution was then evaporated on water bath at 
$80^{\circ} \mathrm{C}$ with constant stirring until a dried precursor was obtained. Fine powder of the dried precursor was then sintered at $500^{\circ} \mathrm{C}$ for $3 \mathrm{~h}$ in an electrical furnace (ASCO, India) to get the desired oxides. Powder X-ray diffractometer (Bruker D-8 advanced series-2) provided with $\mathrm{Cu}-\mathrm{K}_{\alpha 1}$ radiation source (wave length $\lambda=1.54056 \AA$ ) was used to identify the phase and crystallite size of the synthesized materials. Texture structure of the oxide in the form of film on $\mathrm{Ni}$ was determined by using scanning electron microscope (SEM; JEOL JSM 6490). Spinel ferrite phase of the material was confirmed by infrared spectra (FT-IR Thermoscientific; Nicole-6700).

Electrochemical characterizations such as cyclic voltammetry (CV) and anodic Tafel polarization have been performed in a three-electrode single compartment glass cell using potentiostat/galvanostat (Gamry Reference 600 ZRA) which contains corrosion and physical electrochemistry software and a desktop computer (HP). A platinum foil $\left(\sim 2 \mathrm{~cm}^{2}\right)$ and $\mathrm{Hg} / \mathrm{HgO} / 1 \mathrm{M} \mathrm{KOH}\left(\mathrm{E}^{\circ}=0.098 \mathrm{~V}\right.$ vs $\mathrm{NHE}$ at $\left.25^{\circ} \mathrm{C}\right)$ were used as an auxiliary and reference electrode, respectively. In order to minimize of the solution resistance (iR drop), the reference electrode was connected electrically to the electrolyte through a Luggin capillary (agar-agar and potassium chloride salt bridge gel). An oxide slurry painting technique $[36,37]$ was used to transfer the oxide powder in the form of film electrode on pre-treated Ni-support. The method of pre-treatment of Ni-support, film preparation and electrical contact with the oxide film were the same as described elsewhere [36, 37]. This oxide film electrode was used as working electrode.

\section{RESULTS AND DISCUSSION}

\subsection{Infrared (IR) spectra}

The IR spectra of oxides recorded in the wave number region of $4000-400 \mathrm{~cm}^{-1}$ was observed to be very much identical to that found with $\mathrm{Ni}$ and Mn-sustituted [29,30] spinel ferrites prepared by the similar egg-white sol-gel route. So, the spectra of the oxide is not given here. Bands $\sim 570$ \& $\sim 460 \mathrm{~cm}^{-1}$ described the formation of pure spinel ferrites $[38,39]$. Other bands at $\sim 3410 \& \sim 1630$ and $1100 \mathrm{~cm}^{-1}$ correspond to the $\mathrm{O}-\mathrm{H}$ stretching vibrations and nitrate ion, respectively.

\subsection{X-ray diffraction (XRD)}

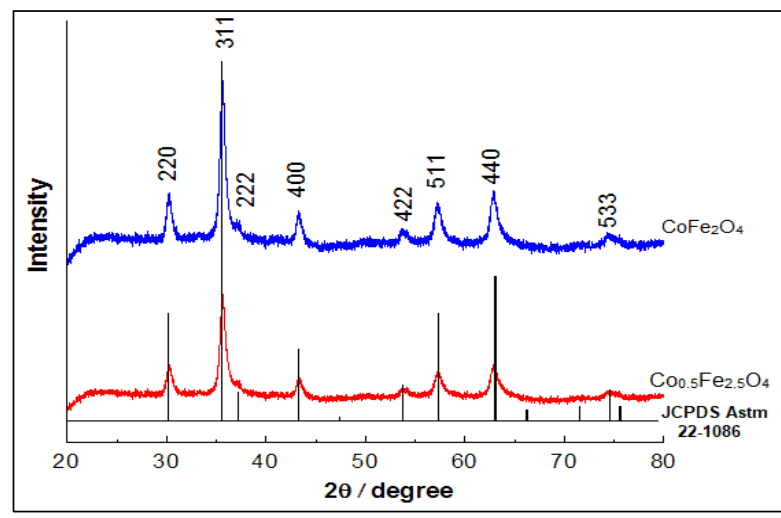

Figure 1. XRD powder patterns of the standard and oxide powder sintered at $500^{\circ} \mathrm{C}$ for $3 \mathrm{~h}$
Figure 1 represents the powder X-Ray diffraction patterns of sintered oxide powders recorded between $2 \theta=20^{\circ}$ and $80^{\circ}$. The analysis of X-ray diffraction patterns shows that oxides are crystallized in cubic crystal geometry and best matched with JCPDS-ASTM file 22-1086 for $\mathrm{CoFe}_{2} \mathrm{O}_{4}$. The crystallite size calculated by using the Scherer's formula [40] was found to be 11 and $15 \mathrm{~nm}$ for $\mathrm{x}=0.5$ and 1.0 , respectively.

\subsection{Scanning electron micrograph (SEM)}

SE micrograph of pure and Co-substituted oxide as shown in Figure 2 was taken in the form of film on Ni-substrate. Texture of oxide film appears to be similar with each oxide except $\mathrm{CoFe}_{2} \mathrm{O}_{4}$ which exists some agglomeration. The figure shows that the distribution of particle is more uniform and more homogeneous in the case of oxides $\mathrm{Fe}_{3} \mathrm{O}_{4}$ and $\mathrm{Co}_{0.5} \mathrm{Fe}_{2.5} \mathrm{O}_{4}$ while it is found to be less homogeneous in case of $\mathrm{CoFe}_{2} \mathrm{O}_{4}$ and $\mathrm{Co}_{1.5} \mathrm{Fe}_{1.5} \mathrm{O}_{4}$.
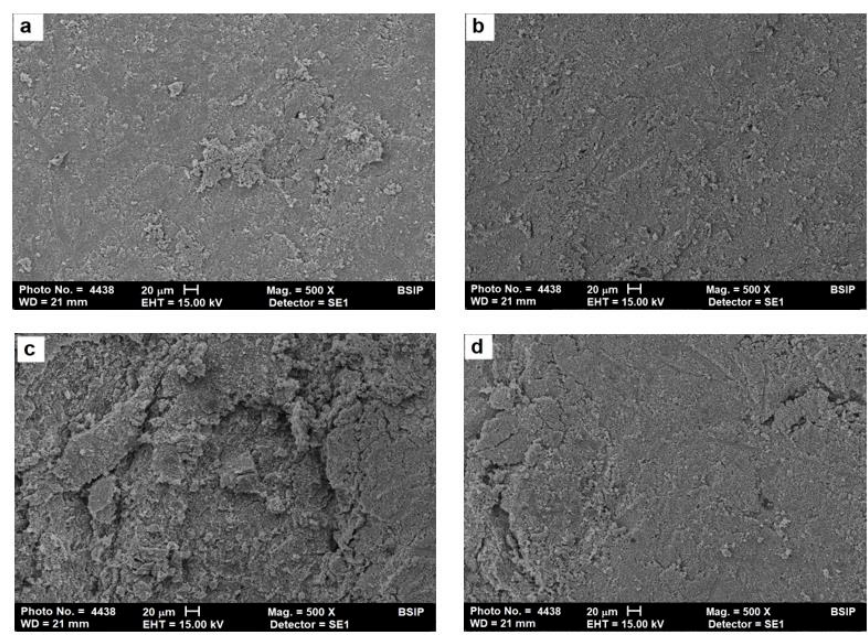

Figure 2. SE Micrographs of oxide film on Ni; a: $\mathrm{Fe}_{3} \mathrm{O}_{4}$; b: $\mathrm{Co}_{0.5} \mathrm{Fe}_{2.5} \mathrm{O}_{4} ; \mathrm{c}: \mathrm{CoFe}_{2} \mathrm{O}_{4} ; \mathrm{d}: \mathrm{Co}_{1.5} \mathrm{Fe}_{1.5} \mathrm{O}_{4}$

\subsection{Cyclic voltammetry (CV)}

Figure 3 shows the cyclic voltammograms of oxide film electrode on Ni-substrate recorded at the scan rate of $20 \mathrm{mV}$ $\mathrm{sec}^{-1}$ in $1 \mathrm{M} \mathrm{KOH}$ at $25^{\circ} \mathrm{C}$ in the potential range between 0.0 to $0.7 \mathrm{~V}$. Nature of the curve was same regardless the substitution of $\mathrm{Co}$ for $\mathrm{Fe}$ in $\mathrm{Fe}_{3} \mathrm{O}_{4}$ lattice. Each voltammogram

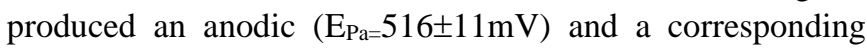
cathodic $\left(E_{P_{c}}=364 \pm 10 \mathrm{mV}\right)$ peak before the onset of oxygen evolution reaction (OER). Similar redox peaks have also been found by some authors [19, 20, 27-31] for the same type of electrode systems. It is also reported that the Ni-support [9, 19, 37] undergoes oxidation and reduction due to the contact with the electrolyte through pores, cracks and intercrystalline gap. The low temperature synthetic routes, generally, produced materials with hygroscopic nature [9, 19] which assists the rapid hydration of materials in aqueous solution and resulting the wetting of the whole film thickness. The catalytic film remains stable during the cyclic process.

Values of other cyclic voltammetric parameters, such as the peak separation potential $\left(\Delta \mathrm{E}=\mathrm{E}_{\mathrm{Pa}}-\mathrm{E}_{\mathrm{Pc}}\right)$ and the formal redox potential $\left.\left[\mathrm{E}^{\circ}=\left(\mathrm{E}_{\mathrm{Pa}}+\mathrm{E}_{\mathrm{Pc}}\right) / 2\right)\right]$ were estimated from the $\mathrm{CV}$ curve and given in Table 1 . The $\Delta \mathrm{E}_{\mathrm{P}}$ value was found to be maximum for 1.5 mol Co substitution in base oxide, while it was found to be minimum with $1.0 \mathrm{~mol}$ Co substituted oxide. The formal 
redox potential was observed to be the same $(437 \pm 3)$ with each oxide electrode.

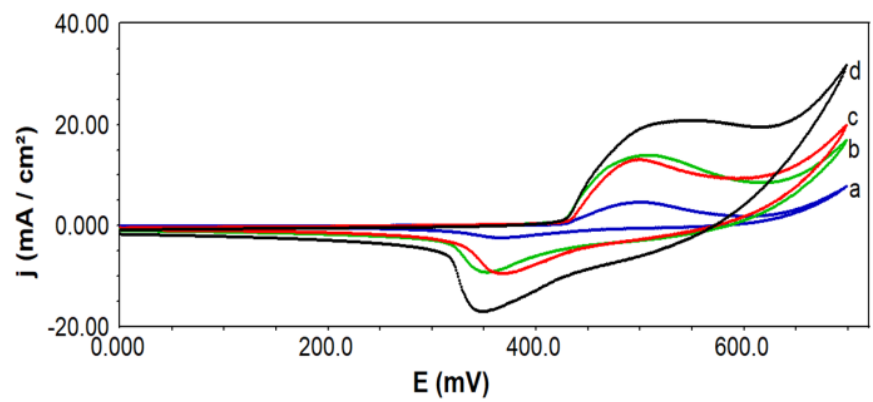

Figure 3. Cyclic voltammogram of $\mathrm{Ni} / \mathrm{Co}_{\mathrm{x}} \mathrm{Fe}_{3-\mathrm{x}} \mathrm{O}_{4}(0 \leq \mathrm{x} \leq 1.5)$ electrode in $1 \mathrm{M} \mathrm{KOH}$ at $25^{\circ} \mathrm{C}$ (scan rates $=20 \mathrm{mV} / \mathrm{sec}$ ) a: $\mathrm{Fe}_{3} \mathrm{O}_{4}$, b: $\mathrm{Co}_{0.5} \mathrm{Fe}_{2.5} \mathrm{O}_{4}$, c: $\mathrm{CoFe}_{2} \mathrm{O}_{4}, \mathrm{~d}: \mathrm{Co}_{1.5} \mathrm{Fe}_{1.5} \mathrm{O}_{4}$

The oxide electrodes have also been tested for the variation of scan rate on cyclic voltammogram. The CV curve was recorded at different potential scan rates between $20-120 \mathrm{mV}$ $\mathrm{sec}^{-1}$ in $1 \mathrm{M} \mathrm{KOH}$ at $25^{\circ} \mathrm{C}$. A representative curve is shown in
Figure 4 for $\mathrm{Ni} / \mathrm{Co}_{0.5} \mathrm{Fe}_{2.5} \mathrm{O}_{4}$. The nature of the $\mathrm{CV}$ curve observed to be identical and exhibited an anodic and corresponding cathodic peaks prior to the OER. But, with the variation of scan rates, these anodic and cathodic peaks were shifted in either directions. The shift in the potential is 80$132 \mathrm{mV}$ in anodic region and $15-32 \mathrm{mV}$ in the cathodic region. Parameters, such as $\mathrm{E}_{\mathrm{Pa}}, \mathrm{E}_{\mathrm{Pc}}, \Delta \mathrm{E}, \mathrm{E}^{\circ}$, anodic peak current $\left(\mathrm{j}_{\mathrm{P}_{\mathrm{a}}}\right)$ cathodic peak current $\left(\mathrm{j}_{\mathrm{P}_{\mathrm{c}}}\right)$ and voltametric charge $(\mathrm{q})$ were determined from the voltammetric curve. It is found that both anodic and cathodic peak currents increased linearly with increase in the scan rates. The ratio of anodic and cathodic peak current was found to be $\sim 2$, which indicated the irreversibility [41-43] of the redox process. The value of $q$ is estimated by integrating the $\mathrm{CV}$ curve from zero to the potential just prior the $\mathrm{OE}$.

The $\left|j_{P}\right|$ vs square root of scan rate and voltammetric charge (q) vs (scan rate) $)^{-1 / 2}$ were constructed for the oxide electrode and are shown in Figure 5 and Figure 6, respectively. The linearity found in these two figures indicates that the surface redox behavior is diffusion controlled [36].

Table 1. Values of the Cyclic Voltammetric parameters of $\mathrm{Ni} / \mathrm{Co}_{\mathrm{x}} \mathrm{Fe}_{3-\mathrm{x}} \mathrm{O}_{4}(0 \leq \mathrm{x} \leq 1.5)$ in $1 \mathrm{M} \mathrm{KOH}$ at $25^{\circ} \mathrm{C}\left(\mathrm{scan} \mathrm{rate}^{2}=20 \mathrm{mVsec}{ }^{-1}\right)$

\begin{tabular}{|c|c|c|c|c|c|c|c|c|}
\hline Electrode & $\mathbf{E P a} / \mathbf{m V}$ & $\mathbf{E P c} / \mathbf{m V}$ & $\Delta \mathbf{E P}_{\mathbf{p}} / \mathbf{m V}$ & $E^{\circ} / \mathbf{m V}$ & $\mathbf{j}_{P_{a}} / \mathbf{m A ~} \mathbf{c m}^{-2}$ & $\mathbf{j}_{\mathbf{P}_{\mathbf{c}}} / \mathbf{m A ~} \mathbf{c m}^{-2}$ & $\frac{\mathbf{j}_{\mathbf{P}_{\mathbf{a}}}}{\mathbf{j}_{\mathbf{P}_{\mathbf{c}}}}$ & $\mathrm{q} / \mathrm{mC} \mathrm{cm}^{-2}$ \\
\hline $\mathrm{Fe}_{3} \mathrm{O}_{4}$ & $506 \pm 6$ & $369 \pm 3$ & $137 \pm 3$ & $438 \pm 4$ & 10.1 & 5.6 & 1.7 & 107.4 \\
\hline $\mathrm{Co} .5 \mathrm{Fe}_{2.5} \mathrm{O}_{4}$ & $514 \pm 9$ & $354 \pm 7$ & $160 \pm 2$ & $434 \pm 8$ & 23.2 & 12.4 & 1.8 & 308.4 \\
\hline $\mathrm{CoFe}_{2} \mathrm{O}_{4}$ & $508 \pm 8$ & $374 \pm 4$ & $134 \pm 4$ & $441 \pm 6$ & 7.5 & 3.1 & 2.3 & 75.0 \\
\hline $\mathrm{Co}_{1.5} \mathrm{Fe}_{1.5} \mathrm{O}_{4}$ & $527 \pm 3$ & $354 \pm 5$ & $173 \pm 2$ & $440 \pm 4$ & 5.2 & 2.6 & 1.9 & 56.7 \\
\hline
\end{tabular}

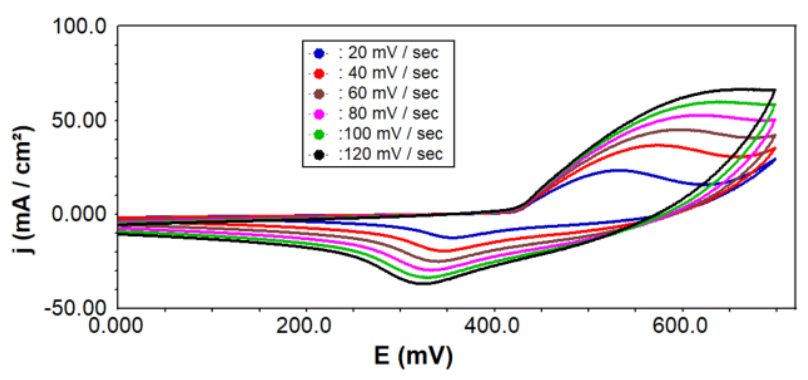

Figure 4. Cyclic voltammograms of the $\mathrm{Co}_{0.5} \mathrm{Fe}_{2.5} \mathrm{O}_{4}$ film electrode on $\mathrm{Ni}$ at different scan rates in $1 \mathrm{M} \mathrm{KOH}\left(25^{\circ} \mathrm{C}\right)$

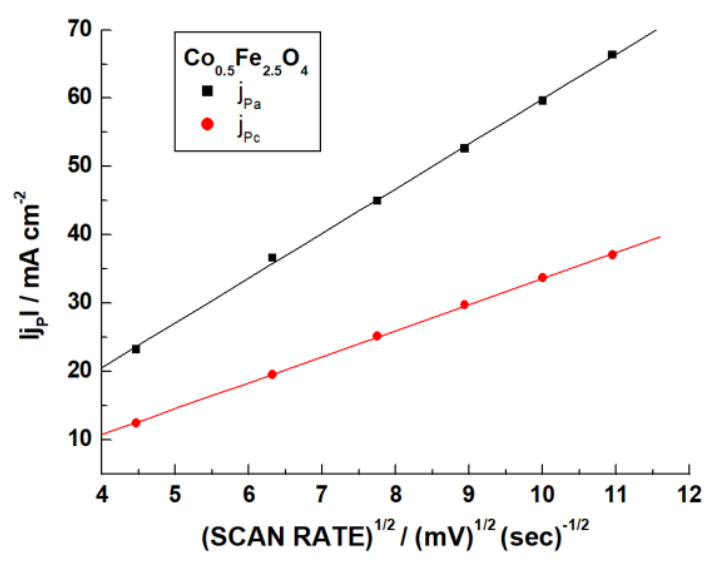

Figure 5. Plot of $\left|j_{\mathrm{P}}\right| \mathrm{vs}$ (scan rate) $)^{1 / 2}$ of the oxide film electrode on $\mathrm{Ni}$ in $1 \mathrm{M} \mathrm{KOH}\left(25^{\circ} \mathrm{C}\right)$

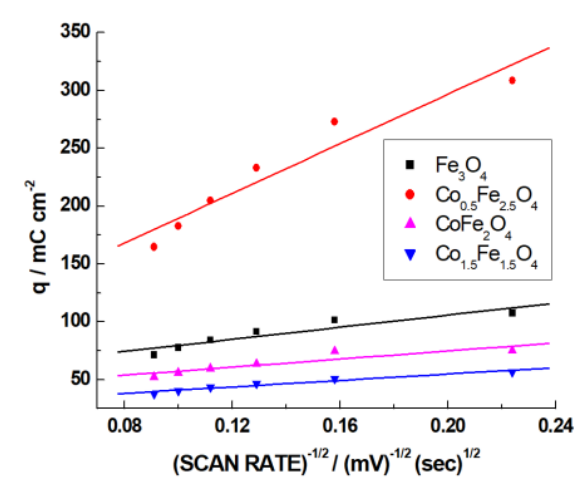

Figure 6. Plot of voltammetric charge (q) vs (scan rate) $)^{-1 / 2}$ for oxide film electrodes on $\mathrm{Ni}\left(25^{\circ} \mathrm{C}\right)$

\subsection{Electrocatalytic activity}

The anodic polarization curve (Figure 7) for each oxide electrode was recorded in $1 \mathrm{M} \mathrm{KOH}$ at $25^{\circ} \mathrm{C}$ at a slow scan rate (SR) of $0.2 \mathrm{mVsec}^{-1}$ and the electrocatalytic activity was determined by estimating the polarization curve in terms of both potential and current density at a fixed current density and potential, respectively. Values, so obtained, are represented in Table 2. The value of Tafel slopes (b) was found to increase with Co-subtitution. Such trend has also been observed in the case of Ni-substituted [29] ferrites. However, it is detected to decrease with Mn-substituted [30] ferrites. From figure 7 and table 2, it is seen that the substitution of Co for Fe increases the electrocatalytic activity of the material and found to be maximun with $0.5 \mathrm{~mol} \mathrm{Co-substitution.} \mathrm{On} \mathrm{the} \mathrm{basis} \mathrm{of} \mathrm{apprant}$ current density (based on geometrical surface area) data at 
certain potential $(\mathrm{E}=750 \mathrm{mV})$, the oxides followed following order of the electrocatalytic activity;

$$
\begin{gathered}
\mathrm{Co}_{0.5} \mathrm{Fe}_{2.5} \mathrm{O}_{4}\left(\mathrm{j}_{\mathrm{a}}=66.8 \mathrm{mAcm}^{-2}\right)>\mathrm{CoFe}_{2} \mathrm{O}_{4}\left(\mathrm{j}_{\mathrm{a}}=49.5\right. \\
\left.\mathrm{mAcm}^{-2}\right)>\mathrm{Co}_{1.5} \mathrm{Fe}_{1.5} \mathrm{O}_{4}\left(\mathrm{j}_{\mathrm{a}}=41.0 \mathrm{mAcm}^{-2}\right)>\mathrm{Fe}_{3} \mathrm{O}_{4} \\
\left(\mathrm{j}_{\mathrm{a}}=29.8 \mathrm{mAcm}^{-2}\right)
\end{gathered}
$$

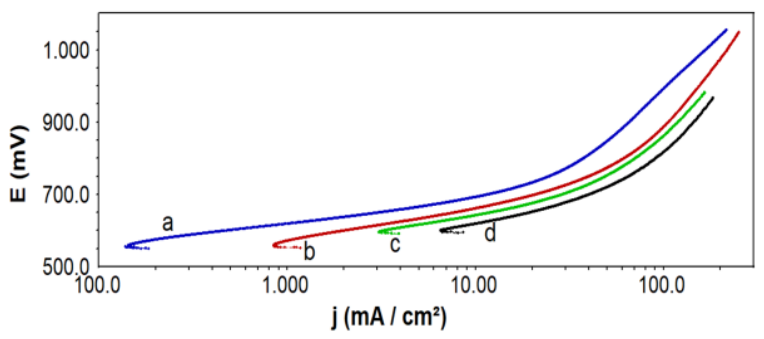

Figure 7. Tafel plot for the $\mathrm{Ni} / \mathrm{Co}_{\mathrm{x}} \mathrm{Fe}_{3-\mathrm{x}} \mathrm{O}_{4}(0 \leq \mathrm{x} \leq 1.5)$ film electrodes in $1 \mathrm{M} \mathrm{KOH}\left(25^{\circ} \mathrm{C}\right) ; \mathrm{SR}=0.2 \mathrm{mVsec}^{-1}$; a: $\mathrm{Fe}_{3} \mathrm{O}_{4}$, b:

$\mathrm{CoFe}_{2} \mathrm{O}_{4}, \mathrm{c}: \mathrm{Co}_{1.5} \mathrm{Fe}_{1.5} \mathrm{O}_{4} \mathrm{~d}: \mathrm{Co}_{0.5} \mathrm{Fe}_{2.5} \mathrm{O}_{4}$
The order of OER with respect to $\mathrm{OH}^{-}$concentration was determined by recording Tafel polarization curves at different $\mathrm{KOH}$ concentrations $(0.25-1.5 \mathrm{M} \mathrm{KOH})$. In order to make the electrical intensity uniform, an inert electrolyte $\mathrm{KNO}_{3}$ was added to each solution to maintain the ionic strength $(\mu=1.5)$ of the medium constant. A representative polarization curve for $\mathrm{Ni} / \mathrm{Co}_{0.5} \mathrm{Fe}_{2.5} \mathrm{O}_{4}$ electrode is shown in Figure 8. The current density value was estimated from the polarization curve recorded at each concentration for every oxide catalyst at a constant applied potential. Generally, first linear Tafel region of the curve was considered for this purpose because second Tafel region undergoes polarization at higher potential. From the data a plot, $\log \mathrm{j}$ vs. $\log \mathrm{C}_{\mathrm{OH}^{-}}$, is constructed at a constant potential $\mathrm{E}=650 \mathrm{mV}$ and shown in the Figure 9. The value of reaction order (p), estimated by measuring the slope of straight line, is found to be almost unity with each oxide electoctatlyst and given in the Table 2 .

\begin{tabular}{|c|c|c|c|c|c|c|}
\hline \multirow{2}{*}{ Electrode } & \multirow{2}{*}{ Tafel slope $/ \mathrm{mVd}^{-1}$} & \multirow{2}{*}{ Order (p) } & \multicolumn{2}{|c|}{$\mathrm{E} / \mathrm{mV}$ at j $\left(\mathrm{mA} \mathrm{cm}^{-2}\right)$} & \multicolumn{2}{|c|}{$\mathbf{j}\left(\mathrm{mA} \mathrm{cm}^{-2}\right)$ at $\mathrm{E} / \mathrm{mV}$} \\
\hline & & & 10 & 100 & 650 & 750 \\
\hline $\mathrm{Fe}_{3} \mathrm{O}_{4}$ & $65 \pm 3$ & 1.3 & $676 \pm 11$ & $974 \pm 18$ & $4.9 \pm 1.8$ & $29.8 \pm 5.5$ \\
\hline $\mathrm{Co} 0.5 \mathrm{Fe}_{2.5} \mathrm{O}_{4}$ & $88 \pm 7$ & 1.0 & $617 \pm 3$ & $816 \pm 3$ & $20.0 \pm 1.0$ & $66.8 \pm 2.4$ \\
\hline $\mathrm{CoFe}_{2} \mathrm{O}_{4}$ & $91 \pm 4$ & 1.0 & $642 \pm 3$ & $860 \pm 4$ & $12.3 \pm 0.6$ & $49.5 \pm 0.8$ \\
\hline $\mathrm{Co}_{1.5} \mathrm{Fe}_{1.5} \mathrm{O}_{4}$ & $94 \pm 8$ & 1.2 & $658 \pm 2$ & $885 \pm 4$ & $7.8 \pm 1.2$ & $41.0 \pm 1.9$ \\
\hline Pure Ni [44] & 75 & --- & 668 & --- & --- & --- \\
\hline
\end{tabular}

Table 2. Electrode kinetic parameters for oxygen evolution reaction on pure and Co-substituted ferrite electrodes in $1 \mathrm{M}$ KOH at $25^{\circ} \mathrm{C}$

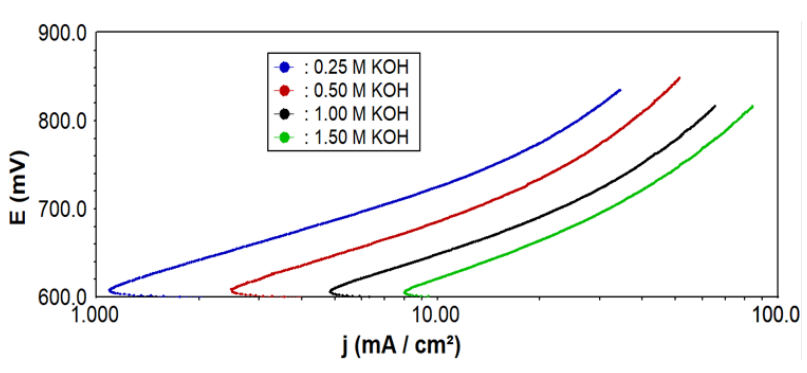

Figure 8. Tafel plots for $\mathrm{Ni} / \mathrm{Co}_{0.5} \mathrm{Fe}_{2.5} \mathrm{O}_{4}$ film electrode at varying $\mathrm{KOH}$ concentrations $(\mu=1.5)$ at $25^{\circ} \mathrm{C}$

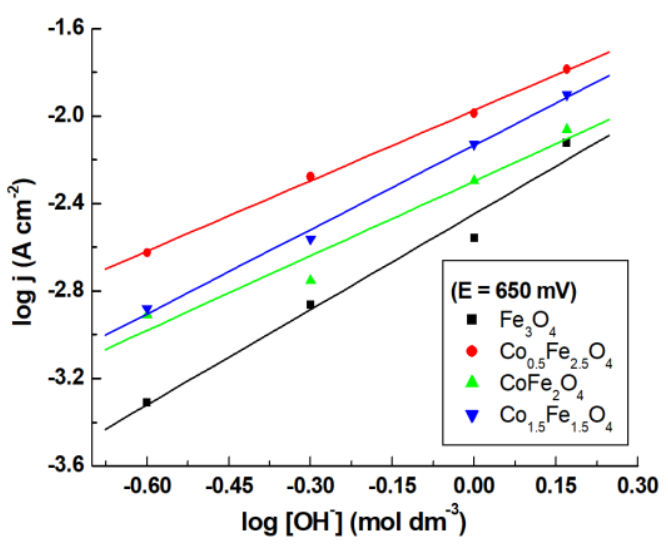

Figure 9. Plot of $\log \mathrm{j}$ vs $\log \left[\mathrm{OH}^{-}\right]$at a constant applied potential for $\mathrm{Ni} / \mathrm{Co}_{x} \mathrm{Fe}_{3-\mathrm{x}} \mathrm{O}_{4}(0 \leq \mathrm{x} \leq 1.5)$ films electrode

It is remarkable that most active electrode of the present study, $\mathrm{Co}_{0.5} \mathrm{Fe}_{2.5} \mathrm{O}_{4}\left(\mathrm{j}=100 \mathrm{mAcm}^{-2}\right.$ at $\left.\mathrm{E}=816 \mathrm{mV}\right)$ has higher electrocatalytic activity as compared those reported in literature. For instance, Iwakura et al. [45, 46] found 743 and $883 \mathrm{mV}$ for $\mathrm{CoFe}_{2} \mathrm{O}_{4}$ and $\mathrm{MnFe}_{2} \mathrm{O}_{4}$, respectively in $1 \mathrm{M} \mathrm{KOH}$ at $25^{\circ} \mathrm{C}$ at relatively low current density of $10 \mathrm{mAcm}^{-2}$. Orehotsky et al. [47] observed similar current density at $\mathrm{E}=643 \mathrm{mV}$ in $30 \mathrm{wt} \% \mathrm{KOH}$. Further, the activity of the oxide $\left(\mathrm{Co}_{0.5} \mathrm{Fe}_{2.5} \mathrm{O}_{4}\right)$ has been found to higher than those obtained by hydrothermal [26] $\left(\mathrm{j}=18.7 \mathrm{mAcm}^{-2}\right.$ at $\left.\mathrm{E}=750 \mathrm{mV}\right), \mathrm{NH}_{4} \mathrm{OH}$ Sol-gel Auto combustion [27] $\left(\mathrm{j}=100 \mathrm{mAcm}^{-2}\right.$ at $\left.\mathrm{E}=828 \mathrm{mV}\right)$, $\mathrm{NH}_{4} \mathrm{OH}-\mathrm{COP}$ [29] $\left(\mathrm{j}=100 \mathrm{mAcm}^{-2}\right.$ at $\left.\mathrm{E}=886 \mathrm{mV}\right), \mathrm{Egg}$-white sol-gel [31] $\left(j=100 \mathrm{mAcm}^{-2}\right.$ at $\left.E=865 \mathrm{mV}\right)$ methods, which are recently reported in literature. However, most of the binary [18-20,28,30] and ternary [21-25, 32] oxides obtained by coprecipitation and other sol-gel routes show better electrocatalytic activity than the oxides conveyed in the present study.

\subsection{Thermodynamic parameters}

In order to know the effect of temperature on the OER and to determine the activation energy for electrochemical reaction with each oxide electrode, anodic polarization curve was recorded in $1 \mathrm{M} \mathrm{KOH}$ at different temperatures $\left(20^{\circ}-50^{\circ} \mathrm{C}\right)$ as shown in Figure 10 for $\mathrm{Ni} / \mathrm{Co}_{0.5} \mathrm{Fe}_{2.5} \mathrm{O}_{4}$ oxide electrode. Value of current density was estimated from the polarization curves at a constant applied potential. The value of electrochemical enthalpy of activation $\left(\Delta \mathrm{H}_{\mathrm{el}}^{\circ \neq}\right)$ for each electrocatalyst was determined by measuring slope of straight line plot, log $\mathrm{j}$ vs. $1 /$ T (Fig 11). The Standard enthalpy of activation $\left(\Delta \mathrm{H}^{\circ \neq}\right)$ and Standard entropy of activation $\left(\Delta S^{\circ \neq}\right)$, were determined by using the following relations (1) and (2), respectively [48];

$$
\Delta \mathrm{H}_{\mathrm{el}}^{\mathrm{o} \neq}=\Delta \mathrm{H}^{\mathrm{o} \neq}-\alpha \mathrm{F \eta}
$$


where, $\alpha(=2.303 \mathrm{RT} / \mathrm{bF})$ is the transfer coefficient. $\eta$ is the overpotential equal to $\mathrm{E}-\mathrm{E}_{2} / \mathrm{OH}^{-}$, where $\mathrm{E}$ is the potential applied and $\mathrm{E}_{\mathrm{O}_{2}} / \mathrm{OH}^{-}(=0.303 \mathrm{~V}$ vs. $\mathrm{Hg} / \mathrm{HgO})$ [15] is the theoretical equilibrium Nernst potential in $1 \mathrm{M} \mathrm{KOH}$ at $25^{\circ} \mathrm{C}$. The term ' $b$ ' is the Tafel slope and determined from the polarization curves obtained at different temperatures. R, F are the universal constants and $\mathrm{T}$ is the absolute temperature.

$$
\Delta \mathrm{S}^{\mathrm{o} \neq}=2.3 \mathrm{R}\left[\log \mathrm{j}+\frac{\Delta \mathrm{H}_{\mathrm{el}}^{\mathrm{o} \neq}}{2.3 \mathrm{RT}}-\log \left(\mathrm{nF} \omega \mathrm{C}_{\mathrm{OH}^{-}}\right)\right]
$$

where, $\omega$ is the frequency term and equal to $k_{\mathrm{B}} T / h . k_{\mathrm{B}}$ and $\mathrm{h}$ are the Boltzmann constant and Plank's constant, respectively. Here, the value of $\mathrm{n}$ is equal to 2 . The calculated values of thermodynamic parameters are listed in the Table 3 . The variation of electrochemical enthalpy of activation $\left(\Delta \mathrm{H}_{\mathrm{el}}^{\circ \neq}\right)$, with applied potentials was also determined by constructing Arrhenius plots (i.e. $\log \mathrm{j}$ vs. $1 / \mathrm{T}$ ) at different potentials ranging from 625 to $700 \mathrm{mV}$ and represented in Figure 12 for $\mathrm{Ni} / \mathrm{Co}_{0.5} \mathrm{Fe}_{2.5} \mathrm{O}_{4}$ electrode. From figure, it is clear that the slope of the straight line deceases with increasing applied potential. The reduction in $\Delta \mathrm{H}_{\mathrm{el}}^{\mathrm{o} \neq}$ has been reported by us earlier [21,30] and also expected as per relation (1).

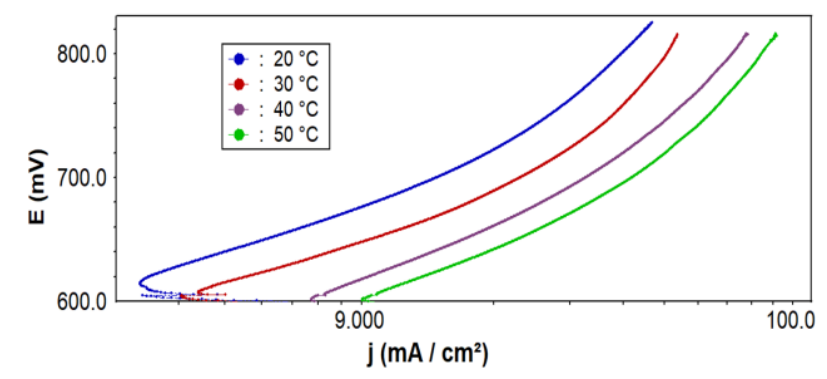

Figure 10. Tafel plots for oxygen evolution on the $\mathrm{Co}_{0.5} \mathrm{Fe}_{2.5} \mathrm{O}_{4}$ film on $\mathrm{Ni}$ at different temperatures in $1 \mathrm{M} \mathrm{KOH}$

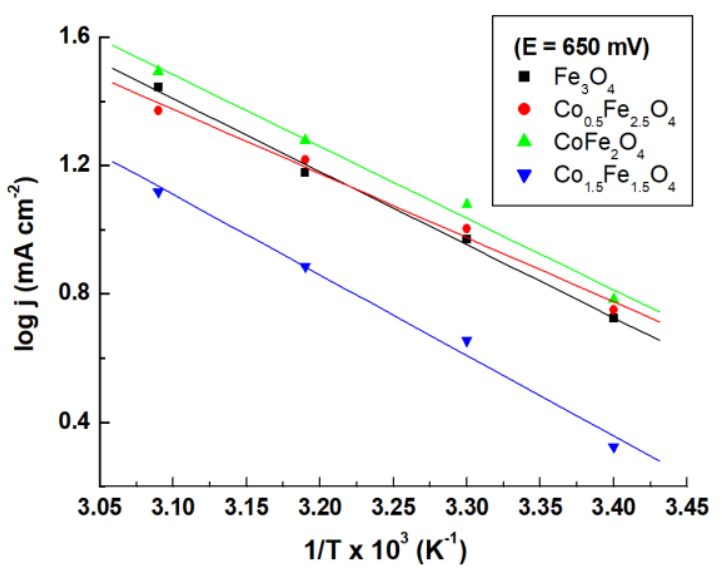

Figure 11. The Arrhenius plot for $\mathrm{Ni} / \mathrm{Co}_{\mathrm{x}} \mathrm{Fe}_{3-\mathrm{x}} \mathrm{O}_{4}$ at a constant applied potential in $1 \mathrm{M} \mathrm{KOH}$

From Table 3, it is observed that the value of electrochemical activation energy did not follow a regular trend with the oxide electrodes and ranged between 38.2 and $48.0 \mathrm{~kJ} \mathrm{~mol}^{-1}$. As expected, the value was found to be minimum most active $\mathrm{Co}_{0.5} \mathrm{Fe}_{2.5} \mathrm{O}_{4}$ electrode. Almost same value of electrochemical activation energy has also been observed by Mills et al. [49] $\left(\Delta \mathrm{H}_{\mathrm{el}}^{\circ \neq}=49 \mathrm{~kJ} \mathrm{~mol}^{-1}\right.$ with Adms$\left.\mathrm{RuO}_{2}\right)$, Kessler et al. [50] $\left(\Delta \mathrm{H}_{\mathrm{el}}^{\circ \neq}=40 \mathrm{~kJ} \mathrm{~mol}^{-1}\right.$ with $\mathrm{Co}_{50} \mathrm{Ni}_{25} \mathrm{~B}_{10}$ alloy), Nikolov et al. [51] $\left(\Delta \mathrm{H}_{\mathrm{el}}^{\circ \neq}=45 \mathrm{~kJ} \mathrm{~mol}^{-1}\right.$ with $\mathrm{Cu}_{0.9} \mathrm{Co}_{2.1} \mathrm{O}_{4}$ ). The highly negative value of $\Delta \mathrm{S}^{\circ \neq}$ indicates the presence of adsorption phenomenon in the electrochemical formation of oxygen.

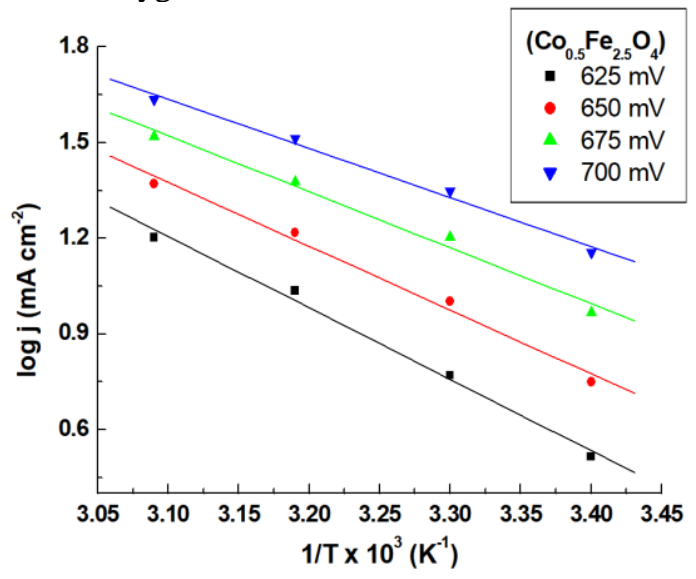

Figure 12. The Arrhenius plot for $\mathrm{Ni} / \mathrm{Co}_{0.5} \mathrm{Fe}_{2.5} \mathrm{O}_{4}$ at different applied potentials in $1 \mathrm{M} \mathrm{KOH}$

Table 3. Thermodynamic parameters for $\mathrm{O}_{2}$ evolution on $\mathrm{Ni} / \mathrm{Co}_{\mathrm{x}} \mathrm{Fe}_{3-\mathrm{x}} \mathrm{O}_{4}(0 \leq \mathrm{x} \leq 1.5)$ in $1 \mathrm{M} \mathrm{KOH}$

\begin{tabular}{|c|c|c|c|c|}
\hline Electrode & $\begin{array}{c}\Delta \mathrm{H}_{\mathrm{el}}^{\circ \neq}(\mathbf{K J} \\
\left.\mathbf{m o l}^{-1}\right) \text { at } \\
\mathbf{E}=\mathbf{6 5 0} \mathbf{m V}\end{array}$ & $\begin{array}{c}-\Delta \mathbf{S}^{\circ \neq}(\mathrm{J} \\
\left.\operatorname{deg}^{-1} \mathrm{~mol}^{-1}\right)\end{array}$ & $\alpha$ & $\begin{array}{c}\Delta \mathbf{H}^{\circ \neq}(\mathbf{K J} \mathbf{J} \\
\left.\mathbf{m o l}^{-1}\right)\end{array}$ \\
\hline $\mathrm{Fe}_{3} \mathrm{O}_{4}$ & 43.5 & 189.0 & 0.7 & 69.9 \\
\hline $\mathrm{Co}_{0.5} \mathrm{Fe}_{2.5} \mathrm{O}_{4}$ & 38.2 & 204.6 & 0.5 & 57.2 \\
\hline $\mathrm{CoFe}_{2} \mathrm{O}_{4}$ & 42.7 & 184.8 & 0.7 & 66.4 \\
\hline $\mathrm{Co}_{1.5} \mathrm{Fe}_{1.5} \mathrm{O}_{4}$ & 48.0 & 163.4 & 0.6 & 69.7 \\
\hline
\end{tabular}

\section{CONCLUSION}

The present work has been undertaken to extend our earlier research work by substituting $\mathrm{Co}$ for $\mathrm{Fe}$ in the $\mathrm{Fe}_{3} \mathrm{O}_{4}$ lattice. IR and XRD study indicate the formation almost pure spinel ferrites. Some agglomeration has been seen in texture of $\mathrm{CoFe}_{2} \mathrm{O}_{4}$. The substitution of Co increased the electrocatalytic activity of the oxides and found to be maximum with $\mathrm{Co}_{0.5} \mathrm{Fe}_{2.5} \mathrm{O}_{4}$. At potential $\mathrm{E}=750 \mathrm{mV}$, this oxide shows almost double current density $\left(\mathrm{j}=66.8 \mathrm{~mA} \mathrm{~cm}^{-2}\right)$ to that of $\mathrm{Fe}_{3} \mathrm{O}_{4}$.

\section{ACKNOWLEDGMENT}

Authors are thankful to BSIP, Lucknow for SEM analysis and Department od Chemistry, University of Lucknow for providing basic infrasturcture to perform the experiments. They are also grateful to SERB (DST), New Delhi for Electrocheical Work Station through Fast Track Scheme for Young Scientist (No.: SR/FT/CS-044/2009).

\section{REFERENCES}

[1] Trasatti, S. (1994). Transition metal oxides: versatile materials for electrocatalysis. The electrochemistry of novel materials, 207-295.

[2] Kung, H.H., Kung, M.C. (1985). Selective oxidative dehydrogenation of butenes on ferrite catalysts. In Advances in catalysis, 33: 159-198. 
https://doi.org/10.1016/S0360-0564 (08)60260-6

[3] Rajaram, R.R., Sermon, P.A. (1985). Adsorption and catalytic properties of $\mathrm{Co}$ x Fe 3-x O 4 spinels. Part 1.Preparation and characterisation of precursors to ammonia-synthesis catalysts. Journal of the Chemical Society, Faraday Transactions 1: Physical Chemistry in Condensed Phases, 81(11): 2577-2591. https://doi.org/10.1039/F19858102577

[4] Lahiri, P., Sengupta, S.K. (1995). Physico-chemical properties and catalytic activities of the spinel series

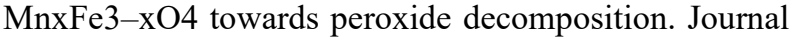
of the Chemical Society, Faraday Transactions, 91(19): 3489-3494. https://doi.org/10.1039/FT9959103489

[5] Cota, H.M., Katan, T., Chin, M., Schoenweis, F.J. (1964). Decomposition of dilute hydrogen peroxide in alkaline solutions. Nature, 203(4951): 1281-1281. https://doi.org/10.1038/2031 281a0

[6] Trasatti, S. (1980). Electrodes of conductive metallic oxides (Vol. 11). Elsevier Science Limited.

[7] Allen, P.D., Hampson, N.A., Bignold, G.J. (1979). The electrodissolution of magnetite: Part I. The electrochemistry of $\mathrm{Fe} 3 \mathrm{O} 4 / \mathrm{C}$ discs-potentiodynamic experiments. Journal of Electroanalytical Chemistry and Interfacial Electrochemistry, 99(3): 299-309. https://doi.org/10.1016/S0022-0728(79)80094-7

[8] O`Sullivan, E.J.M., Calvo E.J. (1987). Comprehensive chemical kinetics, Elsevier, Amsterdam, 27: 263-274.

[9] Trasatti, S., Lipkowski, J., Ross, P.N. (1994). Electrochemistry of Novel Materials. Frontiers of Electrochemistry, $\mathrm{VCH}$.

[10] Tavares, A.C., Bochatay, L., Pereira, M.D.S., Da Costa, F.M.A. (1996). Oxygen evolution on NiCo2- xRhxO4 spinel system. Electrochimica acta, 41(13): 1953-1959. https://doi.org/10.1016/0013-4686(95)00483-1

[11] Tavares, A.C., Cartaxo, M. A. M., da Silva Pereira, M. I., \& Costa, F. M. (2001). Electrochemical study of spinel oxide systems with nominal compositions $\mathrm{Ni} 1-\mathrm{x} \mathrm{Cu} \mathrm{x}$ Co $2 \mathrm{O} 4$ and NiCo 2- y Cu y O 4. Journal of Solid State Electrochemistry, 5(1), 57-67. https://doi.org/10.1007/s100089900091

[12] Tavares, A.C., Cartaxo, M.A.M., da Silva Pereira, M.I., Costa, F.M. (1999). Effect of the partial replacement of $\mathrm{Ni}$ or $\mathrm{Co}$ by $\mathrm{Cu}$ on the electrocatalytic activity of the $\mathrm{NiCo} 2 \mathrm{O} 4$ spinel oxide. Journal of Electroanalytical Chemistry, 464(2): 187-197. https://doi.org/10.1016/S0022-0728(99)00018-2

[13] Rios, E., Gautier, J.L., Poillerat, G., Chartier, P. (1998). Mixed valency spinel oxides of transition metals and electrocatalysis: case of the $\mathrm{MnxCo} 3-\mathrm{xO} 4$ system. Electrochimica Acta, 44(8-9): 1491-1497. https://doi.org/10.1016/S0013-4686(98)00272-2

[14] Švegl, F., Orel, B., Grabec-Švegl, I., Kaučič, V. (2000). Characterization of spinel $\mathrm{Co} 3 \mathrm{O} 4$ and $\mathrm{Li}$-doped $\mathrm{Co} 3 \mathrm{O} 4$ thin film electrocatalysts prepared by the sol-gel route. Electrochimica Acta, 45(25-26): 4359-4371. https://doi.org/10.1016/ S0013-4686(00)00543-0

[15] Singh, R.N., Pandey, J.P., Singh, N.K., Lal, B., Chartier, P., Koenig, J.F. (2000). Sol-gel derived spinel MxCo3$\mathrm{xO} 4(\mathrm{M}=\mathrm{Ni}, \mathrm{Cu} ; 0 \leq \mathrm{x} \leq 1)$ films and oxygen evolution. Electrochimica Acta, 45(12): 1911-1919. https://doi.org/10.1016/S0013-4686(99)00413-2

[16] Lal, B., Singh, N.K., Samuel, S., Singh, R.N. (1999). Electrocatalytic properties of $\mathrm{CuxCo} 3-\mathrm{xO} 4(0<=\mathrm{x}<=1)$ obtained by a new precipitation method for oxygen evolution. Journal of New Materials for Electrochemical Systems, 2(1): 59-64

[17] Lal, B., Singh, R.N., Singh, N.K. (2018). Synthesis and electrocatalytic properties of ni-substituted $\mathrm{Co} 3 \mathrm{O} 4$ for oxygen evolution in alkaline medium. Journal of New Materials for Electrochemical Systems, 21(3): 163-170. https://doi.org/10.14447/jnmes.v21i3.a06

[18] Singh, J.P., Singh, N.K., Singh, R.N. (1999). Electrocatalytic activity of metal-substituted $\mathrm{Fe} 3 \mathrm{O} 4$ obtained at low temperature for $\mathrm{O} 2$ evolution. International journal of hydrogen energy, 24(5): 433-439. https://doi.org/10.1016/S0360-3199(98)00084-6

[19] Singh, N.K., Tiwari, S.K., Anitha, K.L., Singh, R.N. (1996). Electrocatalytic properties of spinel-type mnxfe3-x o4synthesized below $100 \mathrm{c}$ for oxygen evolution in koh solutions. Journal of the Chemical Society, Faraday Transactions, 92(13): 2397-2400. https://doi.org/10.1039/FT9969202397

[20] Singh, N.K., Singh, R.N. (1999). Electrocatalytic properties of spinel type $\mathrm{Ni}$ x $\mathrm{Fe} 3$-x $\mathrm{O} 4$ synthesized at low temperature for oxygen evolution in $\mathrm{KOH}$ solutions. 38A: 491-495.

[21] Singh, R.N., Singh, N.K., Singh, J.P. (2002). Electrocatalytic properties of new active ternary ferrite film anodes for $\mathrm{O} 2$ evolution in alkaline medium. Electrochimica acta, 47(24): 3873-3879. https://doi.org/10.1016/ S0013-4686(02)00354-7

[22] Singh, R.N., Singh, J.P., Lal, B., Thomas, M.J.K., Bera, S. (2006). New NiFe2- xCrxO4 spinel films for $\mathrm{O} 2$ evolution in alkaline solutions. Electrochimica acta, 51(25): $5515-5523$ https://doi.org/10.1016/j.electacta.2006.02.028

[23] Singh, R.N., Singh, J.P., Cong, H.N., Chartier, P. (2006). Effect of partial substitution of $\mathrm{Cr}$ on electrocatalytic properties of $\mathrm{MnFe} 2 \mathrm{O} 4$ towards $\mathrm{O} 2$-evolution in alkaline medium. International journal of hydrogen energy, 31(10): $1372-1378$ https://doi.org/10.1016/j.ijhydene.2005.11.012

[24] Singh, R.N., Singh, J.P., Lal, B., Singh, A. (2007). Preparation and characterization of $\mathrm{CuFe} 2-\mathrm{xCrxO} 4(0 \leqslant$ $\mathrm{x} \leqslant 1.0$ ) nano spinels for electrocatalysis of oxygen evolution in alkaline solutions. International journal of hydrogen energy, 32(1): 11-16. https://doi.org/10.1016/j.ijhydene.2006.06.001

[25] Singh, R.N., Singh, N.K., Singh, J.P., Balaji, G., Gajbhiye, N.S. (2006). Effect of partial substitution of $\mathrm{Cr}$ on electrocatalytic properties of $\mathrm{CoFe} 2 \mathrm{O} 4$ towards $\mathrm{O} 2-$ evolution in alkaline medium. International journal of hydrogen energy, 31(6): 701-707. https://doi.org/10.1016/j.ijhydene.2005.07.0 03

[26] Al-Hoshan, M.S., Singh, J.P., Al-Mayouf, A.M., AlSuhybani, A.A., Shaddad, M.N. (2012). Synthesis, physicochemical and electrochemical properties of nickel ferrite spinels obtained by hydrothermal method for the oxygen evolution reaction (OER). Int. J. Electrochem. Sci, 7: 4959-4973.

[27] Yadav, R., Yadav, M.K., Singh, N.K. (2013). Electrocatalytic Properties of Sol-Gel Derived Spinel CoxFe3-xO4 $(0 \leq x \leq 1.5) \quad$ Electrodes for Oxygen Evolution in Alkaline Solution. Int. J. Electrochem. Sci, 8: 6321-6331.

[28] Yadav, R., Singh, N.K. (2015). Electrocatalytic properties of cobalt ferrites obtained by glycine sol-gel route for oxygen evolution in alkaline medium. 54A: 
1221-1225.

[29] Yadav, R., Jhasaketan, Singh, N.K. (2015). Electrocatalytic Activity of NixFe3-xO4 $(0<=x<=1.5)$ Obtained by Natural Egg Ovalbumin for Alkaline Water Electrolysis. International Journal of Electrochemical Science, 10(11): 9297-9309.

[30] Singh, N.K., Yadav, R., Yadav, M.K. (2016). Electrocatalytic Properties of Egg-white Sol-gel Derived Mn x Fe 3-x O $4(0 \leq x \leq 1.5)$ for Alkaline Water Electrolysis. Journal of New Materials for Electrochemical Systems, 19(4): 209-215. https://doi.org/10.14447/jnmes.v19i4.281

[31] Singh, N.K. (2018). Electrocatalytic activity of NixFe3$\mathrm{xO} 4(0 \leq \mathrm{x} \leq 1.5)$ film electrode for oxygen evolution in $\mathrm{KOH}$ solutions. Indian Journal of Chemical Technology (IJCT), 25(2): 189-195.

[32] Singh, N.K., Yadav, R., Yadav, M.K., Fernandez, C. (2017). Effect of Co-substitution on the Electrocatalytic Properties of Ni 1.5 Fe 1.5 O 4 for Oxygen Evolution in Alkaline Solutions. Journal of New Materials for Electrochemical Systems, 20(3): 115-121. https://doi.org/10.14447/jnmes.v20i3.317

[33] Maensiri, S., Masingboon, C., Boonchom, B., Seraphin, S. (2007). A simple route to synthesize nickel ferrite (NiFe2O4) nanoparticles using egg white. Scripta materialia, $\quad 56(9)$ : $\quad$ 797-800. https://doi.org/10.1016/j.scriptam at.2006.09.033

[34] Lu, R., Yang, D., Cui, D., Wang, Z., \& Guo, L. (2012). Egg white-mediated green synthesis of silver nanoparticles with excellent biocompatibility and enhanced radiation effects on cancer cells. International journal of nanomedicine, 7: 2101.2107. https://doi.org/10.2147/IJN.S29762

[35] Mine, Y. (2002). Recent advances in egg protein functionality in the food system. World's poultry science journal, 58(1): 31-39. https://doi.org/10.1079/WPS20020005

[36] Singh, R.N., Tiwari, S.K., Singh, S.P., Singh, N.K., Poillerat, G., Chartier, P. (1996). Synthesis of (La, Sr) $\mathrm{CoO} 3$ perovskite films via a sol-gel route and their physicochemical and electrochemical surface characterization for anode application in alkaline water electrolysis. Journal of the Chemical Society, Faraday Transactions, 92(14): 2593-2597. https://doi.org/10.1039/FT9969202593

[37] Tiwari, S.K., Chartier, P., Singh, R.N. (1995). Preparation of Perovskite-Type Oxides of Cobalt by the Malic Acid Aided Process and Their Electrocatalytic Surface Properties in Relation to Oxygen Evolution. Journal of The Electrochemical Society, 142(1): 148. https://doi.org/10.1149/1.2043854

[38] Okasha, N. (2004). Structural characterization and magnetic properties of $\mathrm{Zn} 1-\mathrm{xCuxCr} 0$. 8Fe1. 2O4; 0.1 $\mathrm{x} \leq 0.9$. Materials chemistry and physics, 84(1): 63-70. https://doi.org/10.1016/j. matchemphys.2003.10.002

[39] Gillot, B., Nivoix, V., Kester, E., Nusillard, O., Villette,
C., Tailhades, P., Rousset, A. (1997). Reactivity toward oxygen and cation distribution in copper-manganese ferrite spinels fine powders. Materials chemistry and physics, 48(2): 111-118. https://doi.org/10.1016/S02540584(97)80103-4

[40] Fradette, N., Marsan, B. (1998). Surface Studies of Cu x Co3- x O 4 Electrodes for the Electrocatalysis of Oxygen Evolution. Journal of the Electrochemical Society, 145(7): 2320. https://doi.org/10.1149/1.1838637

[41] Wu, W., Guo, S., Zhang, J. (2018). Electrochemical Behaviors of $\mathrm{Cr}$ (III) in Molten LiF-NaF-KF Eutectic. Int. J. Electrochem. Sci, 13: 225-234.

[42] Massot, L., Chamelot, P., Cassayre, L., Taxil, P. (2009). Electrochemical study of the Eu (III)/Eu (II) system in molten fluoride media. Electrochimica acta, 54(26): 6361-6366. https://doi.org/10.1016/j.electacta.2009.06.016

[43] Bard, A.J., Faulkner, L.R. (2001). Electrochemical Methods: Principles and Applications, 2nd (Ed), Wiley, New York.

[44] Cossar, E., Oyarce Barnett, A., Seland, F., Baranova, E.A. (2019). The performance of nickel and nickel-iron catalysts evaluated as anodes in anion exchange membrane water electrolysis. Catalysts, 9(10): 814. https://doi.org/10.3390/cat al9100814

[45] Iwakura, C., Nishioka, M., Tamura, H. (1982). Oxygen evolution on spinel-type ferrite film electrodes. Nippon Kagaku Kaishi, 7: 1136-1140. https://doi.org/10.1246/nikkashi.1982.1136

[46] Iwakura, C., Nishioka, M., Tamura, H. (1981). Relation between oxygen overpotential and magnetic property of spinel type ferrite thin layer electrodes. Denki Kagaku, 49: 535-536.

[47] Orehotsky, J., Huang, H., Davidson, C.R., Srinivasan, S. (1979). Oxygen evolution on NixFe3- xO4 electrodes. Journal of Electroanalytical Chemistry and Interfacial Electrochemistry, $\quad 95(2)$ : 233-235. https://doi.org/10.1016/ S0022-0728(79)80324-1

[48] Gileadi E. (1993). Electrode Kinetics. VCH Publishers Inc., New York, 151.

[49] Mills, A., Davies, H.L. (1992). Oxygen evolution redox catalysis using Ru-Adams. Electrochimica acta, 37(7): 1217-1225. 4686(92)85059-T

[50] Kessler, T., Triaca, W.E., Arvia, A.J. (1994). Kinetics and mechanism of the oxygen evolution reaction at oxide-coated Co-Ni amorphous alloy electrodes. Journal of applied electrochemistry, 24(4): 310-315. https://doi.org/10.1007/BF00 242058

[51] Nikolov, I., Darkaoui, R., Zhecheva, E., Stoyanova, R., Dimitrov, N., Vitanov, T. (1997). Electrocatalytic activity of spinel related cobalties $\mathrm{MxCo} 3-\mathrm{xO} 4(\mathrm{M}=\mathrm{Li}$, $\mathrm{Ni}, \mathrm{Cu}$ ) in the oxygen evolution reaction. Journal of Electroanalytical Chemistry, 429(1-2): 157-168. https://doi.org/10.1016/S0022-0728(96)05013-9 